ACTA MYCOLOGICA

Vol. 42 (1): 79-84

2007
Dedicated to Professor Alina Skirgietto on the occasion of her ninety-fifth birthday

\title{
Species of anamorphic fungi rare and new for Poland
}

\author{
IWONA ADAMSKA
}

\author{
Department of Plant Pathology, University of Agriculture \\ Słowackiego 17, PL-71-434 Szczecin, iwonaadamska@interia.pl
}

Ad a m sk a I.: Species of anamorphic fungi rare and new for Poland. Acta Mycol. 42 (1):79-84, 2007.

Morinia pestalozzioides, Seimatosporium hypericinum, Septoria artemisiae, S. artemisiaemaritimae, S. achilleicola and S. symphyti, fungi not recorded in Poland before, are described and illustrated. The species were found during studies on the occurrence of parasitic fungi conducted in selected sites in the Słowiński National Park and in the Western Pomerania between 2001 and 2004.

Key words: Morinia, Seimatosporium, Septoria, Słowiński National Park, parasitic fungi

\section{INTRODUCTION}

Achillea ptarmica, Artemisia vulgaris, Hypericum perforatum, and Symphytum officinale are plants of considerable pharmaceutical importance in the climatic zone of Poland. Their green parts (A. ptarmica, Ar. vulgaris and $H$. perforatum), roots (A. ptarmica and S. officinale), and capitula (A. ptarmica) are used in drug and cosmetic production (Podbielkowski, Sudnik-Wójcikowska 2003). These plants may be encountered in shrubs and meadows, on hills, and riverbanks, and occur commonly in the lowland part of Poland.

During studies conducted in the Słowiński National Park (SNP) and the Western Pomerania (WP), Achillea ptarmica, Artemisia vulgaris, Ar. campestris subsp. sericea, Hypericum perforatum, and Symphytum officinale were frequently recorded to be infected by parasitic fungi. Among the fungi identified, Morinia pestalozzioides, Septoria achilleicola, S. artemisiae, S. artemisiae-maritimae and S. symphyti occurred, fungi previously not reported from Poland. The species are described and illustrated below. 


\section{MATERIAL AND METHODS}

In the years 2001 to 2004, diseased stems and leaves of plants growing in the Diantho-Armerietum elongatae Krausch 1959, Helichryso-Jasionetum litoralis Libb. 1940, Myrico-Salicetum auritae (Allg. 1922) R. Tx. et Pass. 1961, and Fraxino-Alnetum W. Mat. (1952) 1987 plant associations of the SNP and WP were collected.

In the laboratory, they were first air dried and then placed into paper envelopes. To identify the parasitic fungi associated with the plant parts collected, thin cuttings were taken from a transverse section of the fungal structures revealed and the plant tissue infected using a safety razor. Subsequently, the cuttings were mounted in a drop of lactic acid placed on a microscopic slide, covered with a cover slip, and observed under the Axiolab Zeiss compound microscope. The structures of the fungi found were measured with a micrometric eyepiece and a screwmicrometer.

The nomenclature of plant associations is according to Matuszkiewicz (2001), and that of plant species follows Mirek et al. (2002). The plant species sampled were identified according to Szafer, Kulczyński, Pawłowski (1969). The fungi found were determined after Brandenburger (1985), Ellis and Ellis (1987), Sutton (1980).

All the specimens of plants and fungi discussed below are deposited at the Department of Plant Pathology University of Agriculture in Szczecin.

\section{RESULTS AND DISCUSSION}

Six anamorphic fungal species new and rare for Poland were found. They colonised leaves of Hypericum perforatum, Artemisia campestris subsp. sericea, A. vulgaris, Achillea ptarmica, and Symphytum officinale.

Symbols:

CaEn - Carici arenariae-Empetretum nigri

DAe - Diantho-Armerietum elongatae

HeJl-Helichryso-Jasionetum litoralis

$\mathrm{MSa}$ - Myrico-Salicetum auritae

FrAl - Fraxino-Alnetum

Morinia pestalozzioides Berl. \& Berk.

Spots on dead stems, subcircular, grey to brown, 2-4 mm diam. Acervuli circular, dark brown to black, $150 \mu \mathrm{m}$ diam. Conidia muriform, with 5 transverse septa and 2-3 vertical septa, 18-25 x 9-12 $\mu \mathrm{m}$. Medial cells brown, terminal cells lightolive to hyaline. Apical cell with 2-3 unbranched, hyaline setulae, 10-12 $\mu \mathrm{m}$ long. On Artemisia campestris L. subsp. sericea: SPN, Łeba, CaEn VI 2002 (Figs 1 A-C).

The conidial dimensions in the material found in the SNP slightly diverged from those given by Saccardo (1892; conidia 22-24 x 8-10 $\mu \mathrm{m}$; apical setulae 14-20 x 1 $\mu \mathrm{m})$ and Sutton (1980; conidia 16-22 x 5-7 ųm; apical setulae 12-19 ųm long).

Distribution. Morinia pestalozzioides has so far been reported from Italy (S u t t o n 1980).

Remarks. According to Su t to (1980), A. camphorata Vill. is another host plant of M. pestalozzioides. 


\section{Seimatosporium hypericinum (Ces.) B. Sutton}

Spots randomly distributed on the upper leaf side, irregular, grey to pale brown, 3-6 mm diam. Acervuli brown to black, 200-250 $\mu \mathrm{m}$ diam. Conidia curved, falcate, 4-celled conidia, 14-15 x 6.5-7.5 $\mu \mathrm{m}$. Two medial cells 4-5 $\mu \mathrm{m}$ long, olive to lightolive. Terminal cells 1-2 $\mu \mathrm{m}$ long, hyaline, with 2 unbranched, straight or curved, hyaline setulae, 12-14 $\mu \mathrm{m}$ long. On Hypericum perforatum L.: WP, Karkowo near Kołobrzeg, DAe VI 2002 (Figs 1 D-F).

The acervular diameter of the specimen found by the present author was convergent with that given by Sutton (1980; diameter above $200 \mu \mathrm{m}$ ). The conidial dimensions in the material found in the SNP slightly diverged from those given by Ellis and Ellis $(1987 ; 15-19 \times$ 4.5-5.5 $\mu \mathrm{m})$ and Sutton (1980; 15-18 x 4.5-5.5 $\mu \mathrm{m})$.

The colour of medial cells in the conidia found in the material collected in the SNP slightly diverged from that given by Ellis and Ellis (1987) and Sutton (1980). According to these authors, these cells were light-brown, while they were lighter, mostly olive, in the material collected in the SNP.

Distribution. POLAND. Seimatosporium hypericinum has already been reported to occur in the Lublin region (Zimowska 2002, 2004; Zimowska, Machowicz-Stefaniak 1999, 2004) and in the Western Pomerania (Adamska 2006). OTHER REGIONS. Seimatosporium hypericinum has so far been reported from Italy, Sweden, Germany, Great Britain, France (Sutton 1980), and Australia (Far r et al. 2007).

Remarks. Apart from $H$. perforatum, another host plant of S. hypericinum is $H$. tetrapterum Fries (E1lis, Ellis 1987).

Septoria achilleicola Melnik

Spots on the upper leaf side, ovoid to circular, pale brown to dark brown, 3-5 mm diam. Pycnidia globose, brown to dark brown, $125 \mu \mathrm{m}$ diam., with a circular ostiolum (15-20 $\mu \mathrm{m})$, immersed in the leaf tissue. Conidia hyaline, filamentous, 4-7 celled, 3237.5 x 2-2.5 (-4) um. On Achillea ptarmica L.: SPN, Kluki, MSa VIII 2001.

The conidial dimensions were within the range given by Teterevnikova- Babajan (1987; 14-40 x 1-2 $\mu \mathrm{m})$; however, the conidia of the specimen collected in the SNP were slightly shorter than those described by Brandenburger (1985; $36-60 \times 1.5-1.8 \mu \mathrm{m})$. The number of septa in the conidia was greater than that given by Teterevnikova-Babajan (1987; 1-2-septate), but close to that given by Brandenburger [1985; 2-4-(6)-septate].

Distribution. Septoria achilleicola has been reported from the European part of Russia, Kazakhstan, and Asia (Teterevnikova-Babajan 1987).

REMARKs. According to Tet e revnikova-Babajan (1987), another host plant of $S$. achilleicola is $A$. salicifolia Besser.

Other fungal species of the genus Septoria infecting plants of the genus Alchemilla are $S$. moschatae F. Mangenot (Brandenburger 1985), S. millefolii (Oudem.) Grove, and S. ptarmicae Pass. (Teterevnikova-Babajan 1987).

\section{Septoria artemisiae Pass.}

Spots distributed on the upper leaf side, subcircular, yellow to pale brown. Pycnidia numerous, globose, brown, 120-150 $\mu \mathrm{m}$ diam., with a circular ostiolum (35 $\mu \mathrm{m}$ diam.), immersed in the leaf tissue. Conidia hyaline, filamentous, aseptate, 35- 
40 x 1-2 $\mu \mathrm{m}$. On Artemisia campestris L. subsp. sericea: SPN, Łeba, HeJl VIII 2002, A. vulgaris L.: SPN, Gać, FrAl IX 2001.

The conidial dimensions of the specimens found by the author of this paper were similar to those given by Brandenburger (1985; 30-33 (57) x 1-1.5 $\mu \mathrm{m})$, Cejp and Jechova $(1967 ; 19.5-57 \times 1-1.5 \mu \mathrm{m})$, and Teterevnikova-Babajan (1987; $20-45$ x 1-1.5 $\mu \mathrm{m})$.

Distribution. Septoria artemisiae has been observed in the European part of the former Soviet Union, the Netherlands, Germany, Romania, the Czech Republic, Slovakia, Hungary, Italy, the US, Asia (Teterevnikova-Babajan 1987), as well as in Bulgaria, Korea, China and India (Far r et al. 2007).

Remarks. Apart from A. vulgaris, other plant hosts of $S$. artemisiae are A. austriaca Jacq., A. dracunculus L., and $A$. scoparia W. et K. (Tet e revnikova-Babajan 1987).

According to Brand e n burge r (1985), plants of the genus Artemisia are infected by three species of the genus Septoria (i. e., S. artemisiae Pass., S. artemisiae-maritimae Lobik, and S. globosa Strasser), and not by five (S. artemisiae, S. artemisiaemaritimae, S. artemisiana Garb., S. moeszii Smarods, S. tabacina Died. var. tabacina, and S. tabacina Died. var. dracunculina D. Bab.) as Teterevnikova-Babajan (1987) found. Brandenburger (1985) considered S. moeszii and S. artemisiana to be synonyms of $S$. globosa. According to Teterevnikova-Babajan (1987), $A$. vulgaris is sometimes also affected by S. artemisiana and S. tabacina var. tabacina.

Septoria artemisiae-maritimae Pass.

Spots on the upper leaf side, circular, grey to pale brown, 1-2 mm diam. Pycnidia flattened, pale brown to brown, 65-95 $\mu \mathrm{m}$ diam., with a circular ostiolum (20-28 $\mu \mathrm{m}$ diam.), immersed in the leaf tissue. Conidia narrowly cylindrical, hyaline, aseptate or 3-5-celled, 25-30 (-35) x 2.5-4 um. On Artemisia campestris L. subsp. sericea: SPN, Łeba, HeJl IX 2002 (Figs 1 G-I).

The conidial dimensions of the specimens found by the author of this paper were similar to those given by Brandenburger $(1985 ; 20-26 \times 2.2-3.6 \mu \mathrm{m})$ and Teter evnikova-Babajan (1987; 19.8-26.3 x 3-4 $\mu \mathrm{m})$.

Distribution. Septoria artemisiae-maritimae has already been observed in the European part of the former Soviet Union and Asia (Teterevnikova-Babajan 1987).

Remarks. According to Te te revnikova-Babajan (1987), another host plant of $S$. artemisiae-maritimae is $A$. maritima L. var. salicina.

\section{Septoria symphyti Cejp}

Spots on the upper leaf side, ovoid to irregular, brown to dark brown, 5-15 mm diam. Pycnidia globose, brown, 80-135 $\mu \mathrm{m}$ diam., immersed in the leaf tissue. Conidia filamentous, hyaline, 4-septate, 37.5 x 1-1.5 $\mu \mathrm{m}$. On Symphytum officinale L.: SPN, Gać, FrAl IX 2004.

The pycnidium diameter and the conidial length in the material collected in the SNP were similar to those of the specimens described by Brandenburger (1985; 90-110 $\mu \mathrm{m}$ diam and 24-48 $\mu \mathrm{m}$ long, respectively). The conidial length and the number of septa in the conidia (3-4-septate) also were similar to those given by Brandenburger (1985); however, the conidia in the material collected in the 
SNP were narrower $(37.5 \times 1-1.5 \mu \mathrm{m})$ than those characterized by Brand e n burger (1985; 24-48 x 1.7-2.6 um).

Distribution. Septoria symphyti has been observed in the Czech Republic, Slovakia, and Bulgaria (Farr et al. 2007).

REMARKs. According to Brande n burger (1985), S. symphyti is the only species of the genus Septoria occurring on plants of the genus Symphytum in Europe.

Acknowledgement. The article was completed as part of studies financed by the State Committee for Scientific Research, grant n 3 PO4 01723.

\section{REFERENCES}

Ada mska I. 2006. Choroby grzybowe ziół i zwalczanie ich sprawców. Progress in Plant Protection 46 (2): 654-656.

Branderburger W. 1985. Parasitische Pilze an Gefäßpflanzen in Europa. Fischer. Stuttgart, New York.

Cejp K., Jechova V. 1967. Beitrag zur Kenntnis einiger tschechoslowakischen Arten der Gattung Septoria Fries. Acta Musei Nationalis Pragae. 23 (4): 101-123.

Ellis M.B., Ellis J.P. 1987. Microfungi on land plants. An Identification Handbook. Croom Helm.

Farr D.F., Rossman A.Y., Palm M.E., Mc Cray E.B. 2007. Fungal Databases, Systematic Botany \& Mycology Laboratory, ARS, USDA. Retrieved March 14, 2007 from http://nt.ars-grin.gov/ fungaldatabases/.

Matuszkiewicz W. 2001. Przewodnik do oznaczania zbiorowisk roślinnych Polski. PWN, Warszawa.

Mirek Z., Piękoś-Mirkowa H., Zając A., Zając M. 2002. Flowering plants and Pteridophytes of Poland. A checklist. Biodiversity of Poland 1: 1-442.

Podbielkowski Z., Sudnik-Wójcikowska B. 2003. Słownik roślin użytkowych. PWRiL. Warszawa.

Saccardo P. A. 1892. Sylloge Fungorum 10: 508.

Sutton B.C. 1980. The Coelomycetes. Fungi Imperfecti with Pycnidia, Acervuli and Stromata. Commonwealth Mycological Institute. Kew, Surrey, England.

Szafer W., Kulczyński S., Pawłowski B. 1969. Rośliny polskie. PWN Warszawa.

Teter revnikowa-Babajan D.N. 1987. Griby roda Septoria w SSSR. Wyd. Akad. Nauk Armeńskiej SSR. Erevan.

Zi imows s a B. 2002. Wpływ warunków hodowli na wzrost, zarodnikowanie i tworzenie struktur morfologicznych przez Seimatosporium hypericinum (Ces.) Sutton. Acta Agrob. 55: 401-410.

Zimowska B. 2004. Occurrence, biology and some morphology elements of Seimatosporium hypericinum, a pathogen of St. Johhn's wort (Hypericum perforatum). Phytopathol. Pol. 34: 41-50.

Zimowska B., Machowicz-Stefa niak Z. 1999. Grzyby występujące na niektórych roślinach zielarskich uprawianych w woj. lubelskim. Bioróżnorodność w fitopatologii europejskiej na przełomie wieków. Streszczenia. Poznań: 155.

Zimowska B., Machowicz-Stefaniak Z. 2004. Grzyby zagrażające uprawie dziurawca zwyczajnego (Hypericum perforatum L.) w województwie lubelskim. Acta Sci. Pol., Hortorum Cultus 3: $61-74$. 
Rzadkie i nowe dla Polski gatunki grzybów anamorficznych

Streszczenie

W latach 2001-2004 w wybranych stanowiskach Słowińskiego Parku Narodowego i Pomorza Zachodniego prowadzono badania nad występowaniem grzybów pasożytniczych. W trakcie badań znaleziono Morinia pestalozzioides, Seimatosporium hypericinum, Septoria artemisiae, S. artemisiae-maritimae, S. achilleicola i S. symphyti, gatunki nowe dla Polski. W artykule opisano i zilustrowano znalezione gatunki grzybów. 


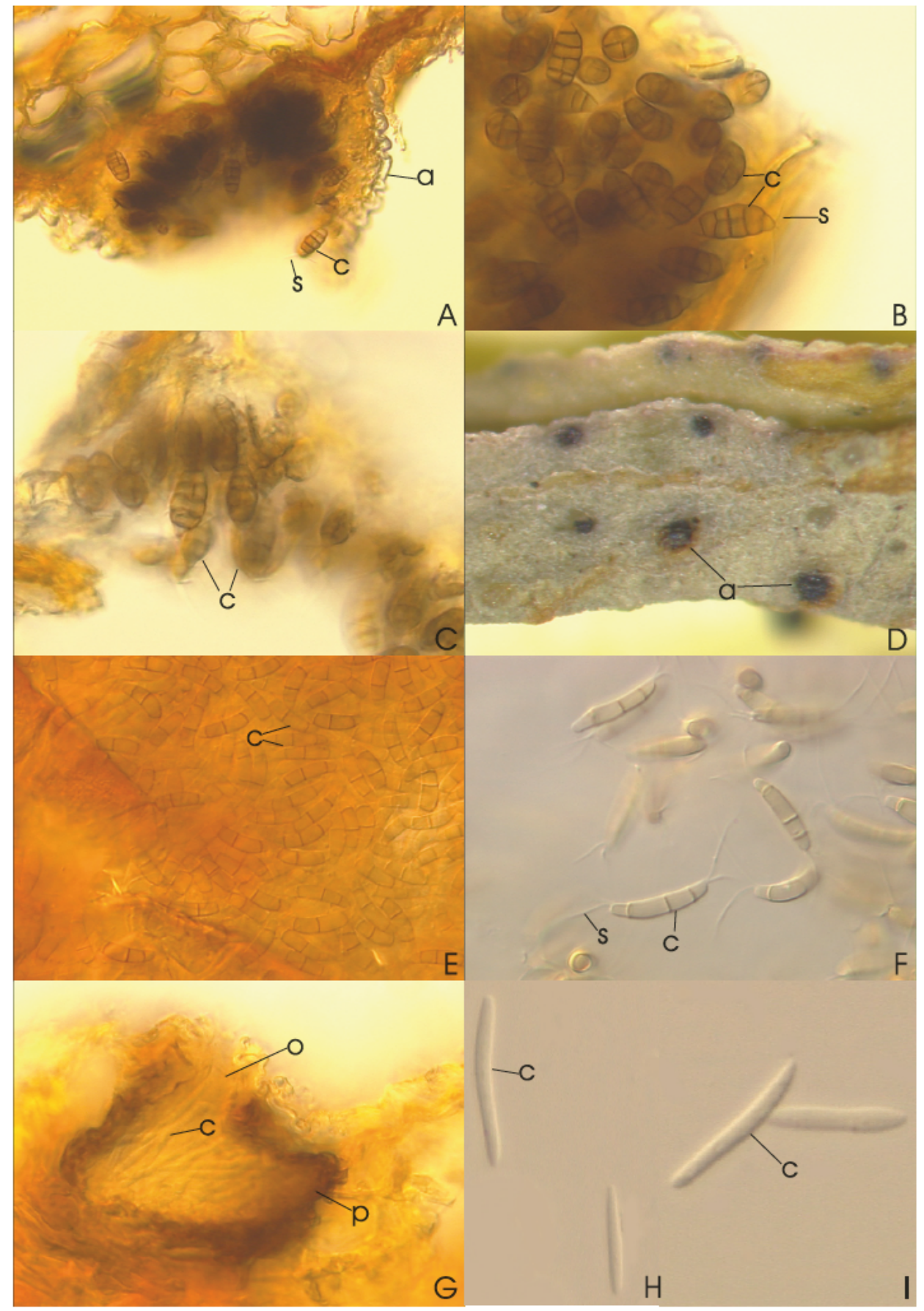

Fig. 1. Morinia pestalozzioides: acervulus (a) with conidia (c; A), conidia (c) with setulae (s; B-C); Seimatosporium hypericinum: acervuli (a) on a leaf of Hypericum perforatum (D), acervulus (a) with conidia (c; E), conidia (c) with setulae (s; F); Septoria artemisiae-maritimae: pycnidium (p) with ostiolum (o) and conidia (c; G), conidia (c; H-I). 